\title{
MOVEMENT ACTIVITY AMONG PATIENTS DIAGNOSED WITH ALCOHOL DEPENDENCE SYNDROME
}

\author{
AKTYWNOŚĆ RUCHOWA WŚRÓd PACJENTÓW ZE ZDIAGNOZOWANYM ZESPOLEM \\ UZALEŻNIENIA OD ALKOHOLU
}

\author{
ДВИГАТЕЛЬНАЯ АКТИВНОСТЬ У ПАЦИЕНТОВ С ДИАГНОСТИРОВАННЫМ СИНДРОМОМ \\ АЛКОГОЛЬНОЙ ЗАВИСИМОСТИ
}

\section{Bewegungsaktivitäten bei Patienten mit diagnostiziertem SYmdrom der ALKOHOLABHÄNGIGKEIT}

\section{ACTIVIDAD MOTRIZ EN PACIENTES DIAGNOSTICADOS CON SÍNDROME DE DEPENDENCIA DEL ALCOHOL}

\author{
Magdalena Zawadzka, Maria Dziedziczak - Buczyńska, Andrzej Buczyński, Gabriela Henrykowska
}

Department of Epidemiology and Public Health, Medical University, Łódź, Poland

Zakład Epidemiologii i Zdrowia Publicznego UM w Łodzi

\section{StRESZCZENIA / ABstracts}

Frequent consumption of large amounts of alcohol usually does not correspond to regular physical activity. However, regular physical activity can lead to an improved well-being and greater satisfaction with life. The aim of the study was to determine the level of physical activity in the group of patients diagnosed with alcohol dependence syndrome and examine the correlation between these variables. The study was conducted among a selected group of individuals of both sexes, aged 22-65 and undergoing treatment. Our study indicated an absence of a correlation between gender and the level of physical activity among people addicted to alcohol. Moreover, no statistically significant relationship was found between alcohol dependence and physical activity undertaken in the researched group.

Keywords: alcoholism, movement activity.

Czeste spożywanie dużych ilości alkoholu zazwyczaj nie koresponduje z regularnym podejmowaniem aktywności fizycznej. Jednak regularna aktywność fizyczna może prowadzić do poprawy samopoczucia i wieksszej satysfakcji z życia Celem badania było określenie poziomu aktywności ruchowej w grupie pacjentów ze zdiagnozowanym zespołem uzależnienia od alkoholu oraz sprawdzenie korelacji między tymi zmiennymi. Badanie przeprowadzono wśród wybranej grupy leczących się osób obojga płci, w wieku 22-65 lat. W badaniu własnym nie odnotowano zależności między płcią a poziomem aktywności fizycznej osób uzależnionych od alkoholu. Nie wykazano również zależności istotnej statystycznie pomiędzy istnieniem uzależnienia od alkoholu a podejmowana aktywnościa fizyczna w badanej grupie.

Słowa kluczowe: alkoholizm, aktywność ruchowa.

Частое употребление большого количества алкоголя обычно не коррелирует положительно с регулярной физической активностью. Однако регулярная физическая активность может привести к улучшению самочувствия и повышению удовлетворенности жизнью. Целью исследования было определение уровня двигательной активности в группе пациентов с диагностированным синдромом алкогольной зависимости, а также проверка корреляции между этими двумя переменными. Исследование проводилось среди избранной группы проходящих лечение пациентов обоих полов в возрасте 22-65 лет. В собственном исследовании не было обнаружено зависимости между полом и уровнем физической активности зависимых от алкоголя людей. Не была также выявлена статистически значимая зависимость между наличием алкогольной зависимости с предпринимаемой физической активностью в группе испытуемых.

Ключевые слова: алкоголизм, двигательная активность.

ARTICLE INFO

PolHypRes 2017 Vol. 61 Issue 4 pp. 67 - 74

ISSN: 1734-7009 eISSN: 2084-0535

DOI: $10.1515 / \mathrm{phr}-2017-0024$

Pages: 8 , figures: 1 , tables: 1

page www of the periodical: www.phr.net.pl

Publisher

Polish Hyperbaric Medicine and Technology Society
Typ artykułu: oryginalny

Original article

Termin nadesłania: $13.09 .2017 \mathrm{r}$

Termin zatwierdzenia do druku: 08.11.2017r. 
Der häufige Genuss großer Mengen Alkohol korrespondiert gewöhnlich nicht mit regelmäßiger körperlicher Anstrengung. Allerdings kann eine regelmäßige körperliche Betätigung zur Besserung des Wohlbefindens und zu höherer Lebenszufriedenheit führen. Ziel der Untersuchung war, das Niveau der Bewegungsaktivitäten in einer Gruppe mit diagnostiziertem Syndrom der Alkoholabhängigkeit festzustellen und die Korrelation zwischen diesen Variablen zu prüfen. Die Untersuchung wurde in einer ausgewählten Gruppe von Patienten beiderlei Geschlechts im Alter von 22 bis 65 Jahren durchgeführt. In der eigenen Untersuchung wurden keine Abhängigkeiten zwischen dem Geschlecht und dem Niveau der körperlichen Aktivitäten von alkoholabhängigen Personen. Es wurde auch keine wesentliche statistische Abhängigkeit zwischen dem Bestehen der Alkoholabhängigkeit und der aufgenommenen körperlichen Aktivität in der untersuchten Gruppe nachgewiesen.

Schlüsselwörter: Alkoholabhängigkeit, Bewegungsaktivitäten.

El consumo frecuente de grandes cantidades de alcohol, por regla general, no corresponde a una actividad física regular. Aunque la actividad física regular puede proporcionar un mayor bienestar y un aumento de la satisfacción en la vida. El objetivo el estudio ha sido delimitar el nivel de actividad motriz en un grupo de pacientes diagnosticados con síndrome de dependencia del alcohol y establecer una correlación entre ambas variables. El estudio fue llevado a cabo en grupos seleccionados de pacientes de entre 22 y 65 años. En el propio estudio, no se observó ninguna relación entre el género y el nivel de actividad física de los dependientes al alcohol. Tampoco se observó una correlación estadísticamente significativa entre la dependencia del alcohol y la actividad física en el grupo estudiado.

Palabras clave: alcoholismo, actividad motriz. 


\section{WSTĘP}

Na przełomie ostatnich lat istotnym elementem życia stała się regularna aktywność fizyczna, mająca dobroczynny wpływ na zdrowie i samopoczucie człowieka. Jej korzystne działanie jest znane bowiem od dawna.

Organizm ludzki jest przystosowany do wykonywania wysiłku fizycznego w określonej ilości i dzięki niemu prawidłowo funkcjonuje. Wysiłek fizyczny powinien być systematyczny, co ma wiele zalet. Niesie za sobą szereg bardzo korzystnych zmian dokonujących się w układzie krwionośnym, oddechowym i kostnym. Wzmacnia on mięsień sercowy, polepsza przepływ krwi w naczyniach krwionośnych, normalizuje ciśnienie krwi, zwiększa stężenie frakcji HDL cholesterolu, zmniejsza stężenie LDL cholesterolu oraz trójglicerydów, w naczyniach krwionośnych zmniejsza ryzyko gęstnienia i wykrzepiania krwi. Ponadto wysiłek fizyczny ma szczególny wpływ na zwiększenie siły mięśni i odporności organizmu, poprawia funkcjonowanie układu oddechowego i dobroczynnie działa na ogólną wydolność ustroju. Pozytywne oddziaływanie aktywności fizycznej szczególnie przejawia się w sferze psychologicznej - prowadzi do polepszenia samopoczucia, zmniejszenia poczucia lęku, głębokości stanów depresyjnych, poprawy snu oraz prowadzi do ogólnego zadowolenia i satysfakcji z życia $[1,2]$.

Częste spożywanie dużej ilości alkoholu i uprawianie regularnej aktywności fizycznej nie jest z sobą kompatybilne, bowiem spożywany w dużej mierze wpływa na organizm, wydajność fizyczną i samopoczucie powodując odwodnienie, problemy żołądkowe, wolniejsze krążenie krwi, słabą koordynacje ruchową, uczucie przemęczenia oraz ogólny brak energii. Alkohol prowadzi do wazodylatacji, czyli do rozkurczu mięśni gładkich w ścianie naczyń krwionośnych. Powoduje to poszerzenie światła naczyń i spadek ciśnienia krwi. To z kolei może prowadzić do zmian normalnego poziomu tętna. Wolniejsze krążenie krwi oznacza gorszą wydajność ćwiczącego podczas treningu [2,3].

Ponadto długotrwałe spożywanie alkoholu uszkadza układ nerwowy i pozbawia osoby uzależnione zdolności kontrolowania swoich odruchów oraz koncentracji, co skutkuje zmniejszoną aktywnością fizyczną. Osłabiona koordynacja ruchowa i niewystarczająca zdolność koncentracji mają wpływ, nawet na bardzo niskim poziomie aktywności ruchowej, na niższą wydajność, wzmożony wysiłek, a nawet duże ryzyko kontuzji lub urazu. Uszkodzenie nerwów natomiast może powodować drętwienie, drżenie kończyn oraz utratę kontroli nad poszczególnymi częściami ciała. U osób z zespołem uzależnienia od alkoholu dochodzi w ostatecznym przypadku do całkowitej utraty zdolności koordynacyjnych. Stan ten związany jest z wpływem alkoholu na neuroprzekaźnik GABA, który działa hamująco na komórki mózgu. Alkohol nasila te właściwości przekaźnika, co prowadzi do niezręczności i spowolnienia odruchów [1,3].

Uczucie przemęczenia oraz zmniejszona ilość energii mogą być wynikiem odwodnienia, ale jest drugi równie istotny czynnik, tj. alkohol działa bardzo depresyjnie. Uczucie smutku, zmęczenia, przygnębienia i braku zadowolenia pojawia się często po wypiciu zbyt dużej ilości alkoholu. Organizm następnego dnia po

\section{INTRODUCTION}

In recent years, regular physical activity has become an important element of life, having a beneficial effect on human health and well-being. Indeed, its favourable effects have been known for a long time.

The human body is accustomed to certain amounts of physical effort and thanks to it, it functions properly. Physical effort should be systematic, which has numerous advantages. It results in a number of highly beneficial changes in the circulatory, respiratory and skeletal systems. It strengthens the heart muscle, improves the blood flow in blood vessels, normalises blood pressure, increases the concentration of HDL cholesterol, reduces the concentration of LDL cholesterol and triglycerides, and reduces the risk of thickening and clotting of blood in blood vessels. Moreover, physical effort has a special effect on increasing muscle strength and immunity of the organism, it improves the functioning of the respiratory system and beneficially affects the general performance of the whole system. The positive impact of physical activity is particularly manifested in the psychological sphere - it leads to an improved well-being, reduced feelings of anxiety, reduction of depression, improvement of sleep and overall satisfaction with life $[1,2]$.

Frequent consumption of large amounts of alcohol and regular physical activity are not compatible as alcohol consumed in excessive amounts to a large extent affects the body, physical performance and well-being causing dehydration, gastric problems, slower blood circulation, poor motor coordination, fatigue and a general lack of energy. Alcohol leads to vasodilatation, i.e. to the relaxation of smooth muscles located in the walls of blood vessels. This results in the widening of the vascular lumina and a drop in blood pressure, which in turn can lead to changes in the heart rate. Slower blood circulation translates into deteriorated efficiency during training $[2,3]$.

In addition, long-term consumption of alcohol damages the nervous system and deprives addicted persons of the ability to control their reflexes and maintain concentration, which results in a reduced physical activity. Reduced motor coordination and insufficient ability to concentrate, even at a very low level of physical activity, results in decreased efficiency, increased effort and even a high risk of injury. Nerve damage, on the other hand, can cause numbness, twitching of the limbs and loss of control over particular parts of the body. Individuals with alcohol dependence syndrome can eventually experience a complete loss of coordination capacity. This condition is related to the effect of alcohol on GABA neurotransmitters which has an inhibitory effect on brain cells. Alcohol intensifies these properties of the transmitter, which leads to clumsiness and deceleration of reflexes $[1,3]$.

The feeling of fatigue and reduced energy may be the result of dehydration, however there is another equally important factor, namely alcohol acts very depressingly. The feeling of sadness, tiredness, depression and lack of satisfaction often appears after drinking too much alcohol. The day following alcohol consumption the body fights the stressors caused by it, thus absorbing some of the energy. When combined with the remaining factors such as stomach problems, 
spożywaniu alkoholu zwalcza stresory nim wywołane, pochłaniając część energii. Kiedy dochodzą do tego pozostałe czynniki, takie jak problemy $\mathrm{z}$ żołądkiem, odwodnienie czy całkowity brak koncentracji, podjęcie aktywności ruchowej staje się bardzo utrudnione, a czasem nawet niemożliwe [2,3].

Jednakże są osoby uzależnione od alkoholu, które preferują zdrowy i aktywny pod względem fizycznym tryb życia. Uprawianie sportu daje w niektórych przypadkach siłę i determinację, aby wytrwać w abstynencji oraz móc czerpać zadowolenie $\mathrm{z}$ życia.

W trakcie leczenia zespołu uzależnienia od alkoholu aktywność fizyczna może być czynnikiem wspomagającym efektywną terapię. Pacjenci często borykają się z depresją, znakomite efekty w jej pozbyciu się i zapobieganiu przynosi właśnie aktywność ruchowa. Uprawianie wszelakich sportów nie tylko posiada pozytywny wpływ na ciało, czy sylwetkę, ale również w dużym stopniu na umysł, jakość życia i sposób postrzegania świata. Poza tym ma jeszcze dobroczynne działanie na kształtowanie pewności siebie, pozytywnego systemu wartości i poczucia mistrzostwa, których to zazwyczaj alkoholikom zdecydowanie brakuje [4]. Dzięki aktywności fizycznej poprawia się przekaz impulsów między komórkami nerwowymi, wzrasta wydzielanie endorfin oraz serotoniny. Sporty grupowe mają dodatkowo to do siebie, że poprawiają zdecydowanie nastrój i kontakty międzyludzkie wśród ćwiczących, co $\mathrm{z}$ kolei stanowi społeczny czynnik wsparcia w walce $\mathrm{z}$ uzależnieniem.

Według Paluska i Schwenk najskuteczniejsze ćwiczenia wspomagające leczenie depresji, a co za tym idzie choroby alkoholowej stanowią: stretching, ćwiczenia rozciągające i aerobowe. W przeciwieństwie do innych ćwiczeń $w$ tym przypadku nie ma znaczenia wielkość i intensywność wysiłku, która by tylko negatywnie działała na obciążenie układu sercowonaczyniowego, ale sam fakt podjęcia nawet najmniejszej aktywności ruchowej w celu dążenia do poprawy jakości życia. Dużą uwagę również dla skuteczności ćwiczeń trzeba przywiązywać do systematyczności. Podsumowując sport jako czynnik profilaktyczny ma duży wpływ na poprawę stanu chorego. W przypadku zdiagnozowania specjalistycznego choroby, psychoterapia $\mathrm{z}$ równoczesnym podejmowaniem aktywności fizycznej oraz w razie konieczności z dodatkową farmakologią, przynoszą najefektywniejsze osiągnięcia w procesie leczenia [4].

Z kolei według danych zaczerpniętych z badań amerykańskich w Nowej Zelandii spożycie alkoholu przez sportowców jest o wiele większe niż u nietrenujących ich rówieśników. Na występowanie takiej sytuacji zapewne składa się bardzo ciężka praca przed ważnymi wydarzeniami, z tym powiązane napięcie emocjonalne, stres oraz późniejsza chęć uczczenia zwycięstwa lub poradzenia sobie z poniesioną porażką przez sportowców [5,6]. Dla niektórych osób alkohol staje się „środkiem pomocniczym" w przełamywaniu granic, zwłaszcza psychicznych, podczas podejmowania różnych form aktywności fizycznej. Takie zachowanie może powodować wypadki oraz poważne konsekwencje zdrowotne, jak to ma miejsce $\mathrm{w}$ przypadku np. nurkowania czy wspinania.

Niestety bardzo mało jest przeprowadzonych badań na temat aktywności fizycznej wśród osób uzależnionych od alkoholu oraz ich zadowolenia z życia. Dlatego też zebrany materiał badawczy ma za zadanie dehydration or total lack of concentration, taking up physical activity becomes very difficult and sometimes even impossible [2,3].

However, there are people addicted to alcohol who prefer a healthy and physically active lifestyle. In some cases, practising sports gives the strength and determination to persevere in abstinence and allows them to find satisfaction in life.

During the treatment of alcohol dependence syndrome, physical activity may be a factor supporting effective therapy. Patients often struggle with depression, and physical activity gives excellent results in its elimination or prevention. Practising all kinds of sports not only positively affects the body or the figure, but it also has a significant impact on the mind, quality of life and perception of the world. Furthermore, it has a beneficial effect on shaping self-confidence, a positive system of values and a sense of mastery, which is usually lacking in alcoholics [4]. Thanks to physical activity, the transmission of impulses between nerve cells is improved, the secretion of endorphins and serotonin increases. Group sports additionally have the effect of improving mood and interpersonal relationships, which in turn constitutes a social support factor in the fight against addiction.

According to the Paluska and Schwenk, the most effective exercises supporting the treatment of depression, and thus alcoholism include: stretching and aerobic exercises. In contrast to other exercises, in this case it is not the size and intensity of the effort that matter, as it would only negatively burden the cardiovascular system, but the very fact of taking up even the smallest physical activity in order to strive to improve one's quality of life. A lot of attention should also be paid to regularity of the exercises. To sum up, sport as a prophylactic factor has a large impact on improving the patient's condition. In the case of diagnosing the disease, psychotherapy combined with activity and, if necessary, with additional pharmacology, result in the most effective treatment process [4].

In turn, according to data from American studies in New Zealand, alcohol consumption by athletes is much higher than that of non-training peers. Such a situation is probably due to very hard work before important events, including the associated emotional tension, stress and the later desire to celebrate victory or cope with the failure suffered by athletes [5,6]. For some people, alcohol becomes the "support measure" in overcoming some barriers, especially mental ones, when taking up various forms of physical activity. This kind of behaviour may cause accidents and serious health consequences, as is the case with e.g. diving or climbing.

Unfortunately, there are very few studies on physical activity among people addicted to alcohol and their satisfaction with life. Therefore, the collected research material is to determine the relationship between a person with alcoholism and his/her approach to practising any kind of physical activity and shaping the level of life satisfaction. The results obtained may contribute to demonstrating the mechanism of alcohol dependence as an unfavourable factor when it comes to practising sports and showing that sports may in fact constitute an alternative to escape from problems and worries accompanying alcoholics. Based on the information obtained from the literature a positive correlation between physical activity at a high or moderate level and a high level of life satisfaction can be expected. 
ustalenie zależności między osobą chorą na alkoholizm a jej podejściem do uprawiania jakiejkolwiek aktywności ruchowej oraz kształtowaniem się poziomu satysfakcji życiowej. Otrzymane wyniki mogą przyczynić się do ujawnienia mechanizmu uzależnienia od alkoholu jako czynnika niesprzyjającego uprawianiu sportu ale za to pomagającemu wyjść z nałogu jako alternatywa ucieczki od problemów, zmartwień i innych utrapień towarzyszącym alkoholikom. Na podstawie uzyskanych informacji z literatury można przewidzieć, że pojawi się tu pozytywny związek pomiędzy aktywnością fizyczną na dużym lub umiarkowanym poziomie, a wysokim stopniem zadowolenia z życia.

\section{Cel PRacy}

Badanie miało na celu określić jaki jest poziom aktywności ruchowej w grupie pacjentów ze zdiagnozowanym zespołem uzależnienia od alkoholu oraz czy występuje korelacja między tymi zmiennymi.

\section{MATERIAE I METODY}

Badanie zostało zrealizowane za zgodą Komisji Bioetyki na Oddziale Leczenia Uzależnień w Wojewódzkim Ośrodku Leczenia Uzależnień przy Szpitalu im. J. Babińskiego w Łodzi, wśród 50 pacjentów obu płci ze zdiagnozowanym zespołem uzależnienia od alkoholu. Przedział wiekowy kształtował się na poziomie od 22 do 65 roku życia. Zostało przebadanych 21 kobiet oraz 29 mężczyzn.

Kryterium decydującym o włączeniu do badań pacjenta była diagnoza zespołu uzależnienia od alkoholu (F10.2) oraz wyrażenie przez uczestnika pisemnej zgody na udział w badaniu. Kryterium wykluczającym pacjenta $\mathrm{z}$ badań był brak zgody na uczestnictwo w danym badaniu oraz występowanie poważnej choroby somatycznej, neurologicznej lub niepełnosprawności ruchowej. Pacjenci posiadali również możliwość odmowy i wycofania zgody na udział w badaniu, w każdej chwili bez podania powodu i jakichkolwiek konsekwencji.

Jednym z narzędzi badawczych wykorzystanym $\mathrm{w}$ badaniu był test MAST - kwestionariusz diagnostyczny zespołu uzależnienia od alkoholu, który ocenia głębokość występującego nałogu. W skład testu wchodzą 24 pytania, na które istnieje tylko możliwa odpowiedź tak lub nie. Otrzymanie przez badanego wyniku kształtującego się powyżej 5 punktów świadczy o tym, iż mamy tu do czynienia z zespołem uzależnienia od alkoholu, poniżej 3 punktów wyklucza daną chorobę [7]

Do oceny poziomu aktywności fizycznej posłużono się Międzynarodowym Kwestionariuszem Aktywności Fizycznej (International Physical Activity Questionnaire-IPAQ). Składa się on z pięciu niezależnych części dotyczących aktywności fizycznej związanej $\mathrm{z}$ pracą zawodową, przemieszczaniem się, $\mathrm{z}$ pracami domowymi, z rekreacją, sportem i aktywnością fizyczną w czasie wolnym. Wynik aktywności fizycznej definiowany jest w jednostkach MET [8].

Analizę statystyczną przeprowadzono w programie STATISTICA 12 PL. Zmienne ciągłe opisano ich wartością minimalną, maksymalną oraz średnią z odchyleniem standardowym. Do weryfikacji hipotez statystycznych posłużyły odpowiednie testy, które dobierano na podstawie rodzaju zmiennych. Do porównań między dwoma grupami niezależnymi

\section{ОВJECTIVE}

The aim of the study was to determine the level of physical activity in the group of patients diagnosed with alcohol dependence syndrome and examine the correlation between these variables.

\section{MATERIAL AND METHODS}

The study was carried out with the consent of the Bioethics Commission at the Addiction Treatment Ward in the Regional Addiction Treatment Centre at the J. Babinski Hospital in Łódź, among 50 patients of both sexes with a diagnosed alcohol addiction syndrome. The age range was between 22 and 65 years. 21 women and 29 men were examined.

The criterion for inclusion of patients in the study was the diagnosis of alcohol dependence syndrome (F10.2) and the participant's written consent to take part in the study. The criterion excluding the patient from the study was the lack of consent for participation in a given study and an occurrence of serious somatic, neurological or physical disability. Moreover, patients had the right to refuse their participation and withdraw the consent to participate in the study, at any time without giving any reason or suffering any consequences.

One of the research tools used in the study was the MAST test - a diagnostic questionnaire for alcohol addiction syndrome, which assesses the severity of existing addiction. The test consists of 24 yes/no questions. Obtaining a result exceeding 5 points by an examined person indicates the presence of alcohol dependence syndrome, whereas the score below 3 points excludes this condition [7].

The International Physical Activity Questionnaire (IPAQ) was used to assess the level of physical activity. It consists of five independent parts related to physical activity connected with work, mobility, housework, recreation, sport and physical activity in leisure time. The result of physical activity is defined in MET units [8].

Statistical analysis was carried out in the STATISTICA 12 PL programme. Continuous variables are described by their minimum, maximum and average values with a standard deviation. Appropriate tests were used to verify the statistical hypotheses, selected based on the type of variables. The student's t test was used for comparisons between the two independent groups. In order to evaluate the relationship between two continuous variables, Pearson's correlation coefficient was used, and the significance level was assumed to be at $\alpha=0.05$.

\section{RESULTS}

Among the respondents, $27(\mathrm{f}=0.54)$ declared vocational or secondary education, while $18(\mathrm{f}=0.36)$ had higher education, five respondents $(f=0.1$ ) had no or primary education. In the study group consisting of people addicted to alcohol, almost half $(\mathrm{N}=23, \mathrm{f}=0.46)$ had a permanent job or ran an independent business. Every fifth respondent $(\mathrm{N}=11, \mathrm{f}=0.22)$ worked parttime, whereas another eleven people $(f=0.22)$ declared receiving a social benefit or using social assistance and having other similar sources of income. Few respondents $(\mathrm{N}=3, \mathrm{f}=0.06)$ were retired or dependent on the family 
wykorzystano test $\mathrm{t}$ studenta. $\mathrm{W}$ celu dokonania oceny zależności między dwoma zmiennymi ciągłymi posłużono się współczynnikiem korelacji Pearsona, poziom istotności przyjęto dla $\alpha=0,05$.

\section{WYNIKI}

Spośród osób badanych, $27 \quad(\mathrm{f}=0,54)$ zadeklarowało wykształcenie zawodowe lub średnie, natomiast $18 \quad(\mathrm{f}=0,36)$ wykształcenie wyższe, pięciu respondentów $(\mathrm{f}=0,1)$ było bez wykształcenia lub miało wykształcenie podstawowe. W badanej grupie osób uzależnionych od alkoholu prawie połowa $(\mathrm{N}=23, \mathrm{f}=0,46)$ posiadała stałą pracę lub prowadziła samodzielną działalność gospodarczą. Co piąty badany $(\mathrm{N}=11, \mathrm{f}=0,22)$ pracował dorywczo, natomiast kolejne jedenaście osób $(\mathrm{f}=0,22)$ deklarowało posiadanie zasiłku lub korzystanie z pomocy społecznej i innych podobnych źródeł utrzymania. Nieliczni respondenci $(\mathrm{N}=3, \mathrm{f}=0,06)$ było na emeryturze lub rencie, lub na utrzymaniu przez rodzinę $(\mathrm{N}=2, \mathrm{f}=0,04)$.

Niemal połowa respondentów ( $\mathrm{f}=0,44, \mathrm{~N}=20$ ) zadeklarowała spożywanie powyżej 20 jednostek alkoholu w tygodniu. Kolejne 15 osób $(\mathrm{f}=0,3)$ oceniło ilość wypijanego alkoholu na 11-20 jednostek w tygodniu. 7 respondentów $(\mathrm{f}=0,14)$ wypijało między 2 a 5 jednostek w ciągu tygodnia, natomiast spożywanie 1 jednostki lub mniej w ciągu tygodnia dotyczyło 2 osób $(\mathrm{N}=0,04)$.

$\mathrm{Na}$ podstawie wyników kwestionariusza IPAQ ustalono, że u ponad połowy tj. N=28, f=0,56 osób z badanej populacji, poziom aktywności fizycznej był niski. W przypadku co czwartego respondenta $(\mathrm{N}=20$, $\mathrm{f}=0,4$ ) poziom aktywności fizycznej oceniono jako przeciętny, natomiast jedynie u nielicznych $(\mathrm{N}=2, \mathrm{f}=0,04)$ stwierdzono wysoki poziom aktywności fizycznej. Ponadto w badanej grupie, średnia wartość wyniku IPAQ (odzwierciedlającego poziom aktywności fizycznej) dla mężczyzn wynosiła 680,34, natomiast dla kobiet 671,90 . Różnica ta nie była istotna statystycznie $(p=0,93)$.
$(\mathrm{N}=2, \mathrm{f}=0.04)$.

Almost half of respondents ( $\mathrm{f}=0.44, \mathrm{~N}=20$ ) declared consumption of more than 20 units of alcohol per week. Another 15 people $(\mathrm{f}=0.3$ ) rated the amount of alcohol consumed at 11-20 units per week. 7 respondents ( $\mathrm{f}=0.14$ ) drank between 2 and 5 units during any given week, while the consumption of 1 unit or less during the week concerned 2 people $(\mathrm{N}=0.04)$.

Based on the results of the IPAQ questionnaire, it was established that in more than half of the people from the studied population, i.e. $\mathrm{N}=28, \mathrm{f}=0.56$, the level of physical activity was low. In the case of every fourth respondent $(\mathrm{N}=20, \mathrm{f}=0.4)$, the level of physical activity was rated as average, while only a few $(\mathrm{N}=2, \mathrm{f}=0.04)$ showed a high level of physical activity. In addition, in the study group, the average value of the IPAQ score (reflecting the level of physical activity) amounted to 680.34 in the case of men and 671.90 in the case of women. This difference was not statistically significant $(\mathrm{p}=0.93)$.

Descriptive statistics for continuous variables in the studied group of people addicted to alcohol. The presented values include the minimum (Min), maximum (Max) and mean (M) values with standard deviations (SD).

Statystyki opisowe dla zmiennych ciągłych w badanej grupie osób uzależnionych od alkoholu. Przedstawiono wartości minimalne (Min), maksymalne (Max) oraz średnie (M) z odchyleniami standardowymi (SD).

\begin{tabular}{lllll}
\hline \multicolumn{1}{c}{ Variable } & MIN & MAX & M & SD \\
\hline age & 22.00 & 65.00 & 41.86 & 12.36 \\
\hline addiction duration & 1.00 & 28.00 & 8.00 & 6.94 \\
\hline IPAQ result & 260.00 & 1560.00 & 676.80 & 299.81 \\
\hline MAST result & 1.00 & 52.00 & 28.42 & 12.38 \\
\hline
\end{tabular}

W badanej grupie osób uzależnionych od alkoholu korelacja między wynikiem MAST a wynikiem kwestionariusza IPAQ była ujemna, nikła oraz nieistotna statystycznie $(R=-0,055, p=0,707)$.
In the researched group of alcohol-dependent individuals, the correlation between the MAST result and the IPAQ questionnaire was negative, negligible and statistically insignificant $(\mathrm{R}=-0.055, \mathrm{p}=0.707)$. 


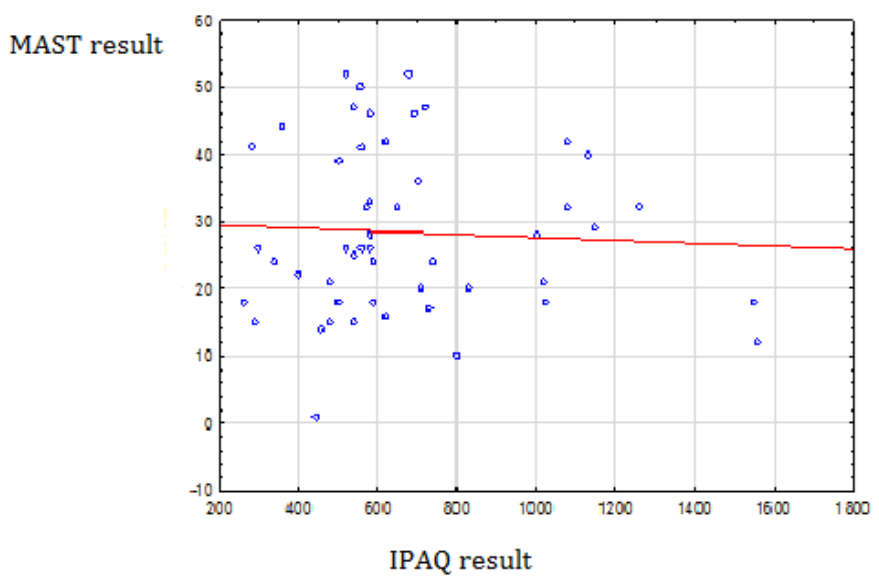

Fig. 1 The spread of results of the Michigan Alcoholism Screening Test (MAST) questionnaire in relation to the International Physical Activity Questionnaire (IPAQ) in the study group of people addicted to alcohol.

Ryc. 1 Rozrzut wyników kwestionariusza Michigan Alcoholism Screening Test (MAST) względem wyników Międzynarodowego Kwestionariusza Aktywności Fizycznej (IPAQ) w badanej grupie osób uzależnionych od alkoholu.

\section{DYSKUSJA I WNIOSKI}

Celem pracy było określenie wpływu głębokości uzależnienia wśród badanej grupy pacjentów na poziom aktywności fizycznej. W badaniu własnym porównanie wyników kwestionariusza MAST z wynikami kwestionariusza IPAQ nie wykazały zależności między tymi dwoma cechami (R=-0,055, p=0,707). Z kolei Amerykańskie Towarzystwo Lekarskie donosi, że choroba alkoholowa a szczególnie jej zaawansowanie ma istotny wpływ na powstanie zaburzeń fizjologicznych, somatycznych i psychicznych, które zdecydowanie utrudniają osiągnięcie wysokiego poziomu aktywności ruchowej przez m.in. zaburzenia $\mathrm{w}$ postrzeganiu zmysłowym i ruchu, neuropatię obwodową, upośledzenie funkcji poznawczych, otępienie. Te przypadłości i wiele innych związanych z alkoholizmem, tworzą podstawy do braku jakiejkolwiek aktywności ruchowej [9]. Natomiast w danej grupie pacjentów nie pojawiło się pod tym względem zależności, co dla nauki jest w pewnym stopniu czymś rzadko spotykanym.

Szukalski potwierdza fakt, że aktywność ruchowa posiada dobroczynny wpływ na zdrowie psychiczne, zmniejsza stany lękowe, zapobiega depresji, a szczególnie poprawia stan emocjonalny [10]. Również Sobolewski wspomina o aktywności ruchowej od najmłodszych lat dla prawidłowego rozwoju psychicznego, aby jak najlepiej radzić sobie w życiu z różnymi problemami i utrzymywać jego jakość na wysokim poziomie [11].

Derbis określił, że człowiek realizujący się $\mathrm{w}$ różnych dziedzinach życia, np. w sporcie, uzewnętrznia przez to jego jakość [12]. Z kolei dla DziurowiczKozłowskiej jakość życia nawiązuje przede wszystkim do prezentowanego poziomu sprawności ruchowej i ogólnego stanu fizycznego, stanu psychicznego, warunków ekonomicznych danego społeczeństwa oraz sytuacji somatycznych doznań [13].

Wyniki badania własnego nie ujawniły zależności między płcią a poziomem aktywności fizycznej osób uzależnionych od alkoholu $(\mathrm{p}=0,93)$. Z kolei Woronowicz stwierdza fakt, że problemy alkoholowe zdecydowanie rzadziej występują u kobiet niż u mężczyzn. Wśród osób leczonych spotyka się 2,5-3 razy mniej kobiet [14]. Niestety w ubiegłych latach zaobserwowano, iż na świecie pojawia się coraz więcej

\section{DISCUSSION AND CONCLUSIONS}

The aim of the study was to determine the influence of the severity of addiction among the studied group of patients on the level of physical activity. In the own study, the comparison of the results of the MAST questionnaire with the results of the IPAQ questionnaire did not reveal a correlation between these two features $(\mathrm{R}=-0.055, \mathrm{p}=0.707)$. In turn, the American Medical Association reports that alcoholism, and especially its severity, has a significant impact on the development of physiological, somatic and mental disorders, which definitely hinder the achievement of a high level of physical activity, inter alia, due to disorders in sensory perception and movement, peripheral neuropathy, cognitive impairment, dementia. These and many other ailments related to alcoholism form the basis for the absence of any kind of physical activity [9]. On the other hand, no correlation in this respect was found in the given group of patients which is somewhat rare in science.

Szukalski confirms the fact that physical activity has a beneficial effect on mental health, reduces anxiety, prevents depression, and in particular improves the emotional state [10]. Sobolewski also mentions that physical activity taken up at an early age is important for proper mental development to cope best with various problems in life and maintain its quality at a high level [11].

Derbis defined that individuals fulfilling themselves in various areas of life, e.g. in sports, thereby externalises its quality [12]. In turn, for DziurowiczKozłowska, the quality of life primarily refers to the presented level of physical fitness and general physical state, mental state, economic conditions of a given society and somatic sensations [13].

Our study indicated no correlations between gender and the level of physical activity among people addicted to alcohol $(p=0.93)$. Woronowicz, on the other hand, states that alcohol problems are much less common in women than in men. Among those treated, female cases are 2.5-3 less frequent [14]. Unfortunately, in recent years it has been observed that the number of addicted women is increasing.

According to modern studies characterised also by Woronowicz, it is revealed that between 50 and $60 \%$ of both women and men are exposed to the alcohol 
kobiet uzależnionych.

Według współczesnych badań scharakteryzowanych również przez Woronowicza ujawnia się, że od 50 do $60 \%$ zarówno kobiet, jak i mężczyzn jest narażonych na zespół uzależnienia od alkoholu głównie zdeterminowany pod względem genetycznym [15]. Dane PARPA ukazują nam, że wśród dorosłych Polaków 25\% sięga co najmniej raz w ciągu tygodnia po alkohol. W tym przypadku mężczyźni stanowia $38 \%$, a kobiety ponad 10\% [16]. Takie zachowanie może przyczyniać się do zwiększonej ilości wypadków podczas uprawiania sportów. Wielu autorów zwraca uwage na alkohol jako na czynnik usposabiający do wystąpienia choroby ciśnieniowej [17]. Dlatego też po jego nadużyciu zabrania się nurkować.

Aktywność fizyczna to bez wątpienia potrzebny element $\mathrm{w}$ naszym życiu. Ma on znaczenie również w niwelowaniu wielu chorób, a także w niektórych przypadkach jest doskonałym elementem procesu leczniczego. Podejmowanie różnych form wysiłku fizycznego daje możliwość poznania nowych ludzi, a tym samym pozwala poczuć się pewniej w kontaktach społecznych, co jest bardzo istotne w terapii uzależnień. Jednak należy pamiętać o pewnych ograniczeniach w podejmowaniu aktywności fizycznej. Wynikać one mogą z leczenia niektórych jednostek chorobowych oraz stosowanej farmakoterapii, co może wykluczać uprawianie np. sportów motorowych czy też nurkowania. addiction syndrome, which is mainly determined genetically [15]. The PARPA data show us that among adult Poles, 25\% reach for alcohol at least once a week. In this case, men account for $38 \%$ whereas women for over $10 \%$ [16]. Such behaviour can contribute to an increased number of accidents during sports. Many authors draw attention to alcohol as a factor predisposing to the occurrence of decompression sickness [17]. Therefore, it is forbidden to perform dives after consuming alcohol.

Physical activity is undoubtedly a necessary element in our lives. It is also important in eliminating many diseases, and in some cases, it is an excellent element of the recovery process. Taking up various forms of physical exercise gives the opportunity to meet new people, and thus allows one to feel more confident in social contacts, which is very important in addiction therapy. However, one should also remember about certain limitations in undertaking physical activity. They may result from the treatment of certain diseases and the applied pharmacotherapy, which may preclude, for instance, practising motor sports or diving.

\section{REFERENCES}

1. Frackowiak M, Motyka M. Alcohol dependence syndrome: characterisation, stages of development, diagnosis. Probl Hig Epidemiol 2015;96(2):315-320;

2. Ryszkowski A, Wojciechowska A, Kopański Z, Brukwicka I, Lishchynskyy I, Mazurek M. Alcohol abuse: symptoms and outcomes. Journal of Clinical Healthcare 2015;1:2-6;

3. Jankowski MM, Ignatowska-Jankowska B, Kumański K, Witek B, Świergiel AH. The effect of alcohol on immunological system - research review. Alcoholism and drug abuse 2013:26(1):37-53;

4. Paluska SA, Schwenk TL. Physical activity and mental health: current concepts. Sport Medicine 2000;29(3):167-180

5. O'Brien KS, Blackie JM, Hunter JA. Hazardous drinking in elite New Zealand sports people, Alcohol and Alcoholism 2005;40:239-241;

6. Garry JP, Morrisessey SI. Team sports participation and risk-taking behaviours among a biracial middle school population. Clinical Journal of Sports Medicine 2000;10:185-190;

7. Bielski J. Methodology of physical and health educations, Oficyna Wydawnicza Impuls, Cracow 2015;46-58;

8. Biernat E, Stupnicki R, Gajewski A. International Physical Activity Questionnaire (IPAQ) - Polish version, Wychowanie Fizyczne i Sport, Warsaw 2007;51(1):47-54;

9. Blair SN, Hardman A. Special issue: Physical activity, health and well-being - an international scientific consensus conference. Research Quarterly for Exercise and Sport 1995;66(4)

10. Szukalski W. Health benefits of physical activity. Lider, 2001;1:15-16;

11. Sobolewski P. Physical activity among youth and their satisfaction with physical education classes. Wychowanie Fizyczne i Zdrowotne, 2003;1:36-37;

12. Derbis R. Everyday life experience. Wydawnictwo Wyższej Szkoły Pedagogicznej, Czestochowa 2000;

13. Dziurowicz - Kozłowska A. Around the quality of life definition. Psychologia Jakości Życia, 2002;1(2):77-96;

14. Woronowicz BT. Alcoholism as a disease. PARPA, Warsaw 1993;

15. Woronowicz BT. Health problems. Addictions. Genesis, therapy, recovery. Parpamedia, Warsaw 2009

16. Zgliczyński WS. Alcohol in Poland. Biuro Analiz Sejmowych, INFOS zagadnienia społeczno-gospodarcze, 2016;11(215):1-4;

17. Kierznikowicz B. Wolański W. Filipek B. Severe decompression sickness in a diver in the course of a training dive. Polish Hyperbaric Research, 2(55), 2016

dr n. med. Magdalena Zawadzka

Zakład Epidemiologii i Zdrowia Publicznego UM w Łodzi

ul. Żeligowskiego $7 / 9$ 90-752 Łódź

magdalena.zawadzka@umed.lodz.pl 